\title{
Bioedusiana
}

http://jurnal.unsil.ac.id/index.php/bioed

DOI: https://doi.org/10.37058/bioed.v6i1.3103

\section{Desain Kegiatan Laboratorium Alternatif: Memfasilitasi Keterampilan Literasi Kuantitatif Siswa melalui Praktikum Respirasi Anaerob}

\section{An Alternative Design of Practical Activities: Facilitating Students' Quantitative Literacy Skills through Anaerobic Respiration Practical Work}

\author{
Aldi Slamet Riyaldi ${ }^{1 *}$, Bambang Supriatno ${ }^{2}$, Sri Anggraeni ${ }^{3}$ \\ ${ }^{123}$ Departemen Pendidikan Biologi, Universitas Pendidikan Indonesia, Jalan Dr. Setiabudi No 229, \\ Bandung, 40154
}

\begin{abstract}
Abstrak
Kegiatan praktikum sangat esensial bagi pembelajaran biologi di sekolah. Namun belum banyak kegiatan praktikum biologi yang mendukung pada kemampuan literasi kuantitatif siswa. Penelitian ini bertujuan untuk memberi gambaran mengenai kualitas desain kegiatan laboratorium (DKL) respirasi anaerob yang tersedia di lapangan serta mengembangkan DKL alternatif yang dapat memfasilitasi keterampilan literasi kuantitatif siswa. Metode penelitian ini adalah deskriptif dengan menggunakan pendekatan ANBUCOR (Analisis, Buat, Coba, dan Rekonstruksi). Tahapan penelitian meliputi analisis DKL lapangan, pembuatan DKL alternatif, uji coba, dan rekonstruksi. Instrumen penelitian berupa rubrik penilaian dan catatan lapangan. Hasil analisis terhadap DKL yang terdapat di lapangan menunjukkan bahwa pada umumnya DKL telah relevan dengan tuntutan kurikulum namun terdapat kelemahan pada aspek kompetensi yaitu pada indikator interpretasi dan representasi data. Hasil pengembangan diperoleh DKL alternatif bersifat eksperimen mencakup alat praktikum yang mendukung kegiatan kuantifikasi dan lembar kerja yang didukung oleh keberadaan beberapa komponen literasi kuantitatif diantaranya kalkulasi, interpretasi, representasi, dan analisis/ aplikasi. Dengan demikian DKL alternatif untuk materi respirasi anaerob yang dikembangkan dapat memfasilitasi keterampilan literasi kuantitatif siswa.
\end{abstract}

Kata kunci: Desain Kegiatan Laboratorium, Keterampilan Literasi Kuantitatif; Praktikum, Respirasi Anaerob.

\begin{abstract}
Practical activities are essential for learning biology in schools. However, there are not many biology practical activities that support students' quantitative literacy skills. This study aims to provide an overview of the quality of the design of laboratory activities (DKL) for anaerobic respiration materials in schools and to develop alternative DKL that can facilitate students' quantitative literacy skills. This research method is descriptive using the ANBUCOR (Analysis, Create, Trials, and Reconstruct) approach. The steps of this research are field DKL analysis, making alternative $D K L$, trial, and reconstruction. The research instrument was an assessment rubric and field notes. The results of the DKL analysis show that generally DKL is relevant to the demands of the curriculum, but there are several weaknesses in the competency aspect such as indicators of data interpretation and representation. The results of the development obtained were experimental alternative DKL including practicum tools that supported quantification activities and worksheets that were supported by the existence of several components of quantitative literacy including calculation, interpretation, representation, and analysis / application. Therefore, the alternative DKL for anaerobic respiration material can facilitate students' quantitative literacy skills.
\end{abstract}

Abstract

Keywords: Design Of Practical Activities, Quantitative Literacy Skills, Practical Work, Anaerobic Respiration.

Article History

Received: May 31 ${ }^{\text {st }}, 2021 ;$ Accepted: June $9^{\text {th }}, 2021$; Published: June 30 $0^{\text {th }}, 2021$

Corresponding Author*

Aldi Slamet Riyaldi, Universitas Pendidikan Indonesia, E-mail: aldisteron@upi.edu

(C) 2021 Bioedusiana. This is an open access article under the CC BY-SA 4.0 license

(https://creativecommons.org/licenses/by-sa/4.0/) 


\section{PENDAHULUAN}

Revolusi Industri 4.0 semakin memberikan perubahan pada segala bidang kehidupan. Tidak terkecuali pada perkembangan sistem informasi. Sejalan dengan hal ini bahwa saat ini dikenal sebagai "big data era", dimana segala bentuk informasi akan berdasarkan pada suatu sumber data besar yang saling terintegrasi. Menurut The National Academic Science, Engineering, and Medicine, keterampilan membaca data secara luas diakui memiliki peran yang semakin penting di tempat kerja masa depan, dan menguasai ilmu tentang data akan menjadi suatu kebutuhan (Gibson \& Mourad, 2018).

Kemampuan menyajikan dan memahami data termasuk kedalam dua dari enam komponen dalam literasi kuantitatif. Literasi kuantitatif saat ini telah menjadi kebutuhan yang sangat esensial bagi setiap individu masyarakat (Sevgi, 2006; Skalicky, 2004). Keterampilan numerik yang semakin baik serta mampu menginterpretasikan data dan mengambil keputusan berdasarkan data harus dimiliki seorang ilmuan di masa yang akan datang (Speth et al., 2010). Seseorang yang memiliki literasi kuantitatif yang baik dapat menilai serta membuat keputusan yang lebih tepat karena didasarkan pada data yang akurat (Kemp, 2003). Sehingga jelaslah bahwa tuntutan jaman saat ini mengarah kepada keterampilan untuk mengaplikasikan literasi kuantitatif dalam kehidupan sehari-hari tidak terkecuali pada praktik pembelajaran Biologi.

Pembelajaran biologi tidak dapat terpisahkan dari kegiatan praktikum atau kegiatan laboratorium. Kegiatan praktikum termasuk kegiatan lapangan merupakan bagian penting dari pendidikan sains (Abrahams \& Millar, 2008). Kegiatan praktikum penting untuk membangkitkan motivasi belajar, mengembangkan keterampilan dasar melakukan eksperimen, menjadi wahana belajar pendekatan ilmiah dan dapat menunjang materi pelajaran (Rustaman et al., 2005). Setiap aktivitas praktikum di laboratorium memiliki tujuan untuk menghubungkan fakta-fakta selama kegiatan berlangsung dengan konsep atau prinsip yang ditemukan. Melalui kegiatan laboratorium, siswa akan bekerja untuk menemukan fakta, prinsip, dan fenomena sendiri melalui observasi untuk menguatkan pengetahuan yang dimilikinya serta mengonstruksi pengetahuan yang baru (Supriatno, 2013). Melalui kegiatan praktikum juga siswa diharapkan memiliki pengalaman belajar untuk memahami konsep.

Kegiatan praktikum dilakukan untuk memberikan pengalaman belajar yang mencakup penemuan konsep dari fakta yang ada, membelajarkan proses menemukan suatu konsep, dan melatih keterampilan proses sains. Pengalaman melalui kegiatan laboratorium merupakan bagian hands on yang secara langsung melibatkan siswa kedalam kegiatan mengumpulkan dan menganalisis informasi, menggambarkan penyelesaian, membuat grafik, peta, gambar, atau kertas kerja untuk membantu mereka berpikir kritis dan mengkomunikasikan (Supriatno, 2013). Sejalan dengan perkembangan kurikulum bahwa kurikulum yang berlaku saat ini telah secara jelas 
memberikan arahan untuk melakukan pengamatan dan pengukuran yang tepat dan teliti, mengolah, menghitung, menyajikan data secara sistematis dan menarik, menginterpretasi, menarik kesimpulan sesuai dengan bukti yang diperoleh (Permendikbud No 24 Tahun 2016). Oleh karena itu kegiatan praktikum biologi hendaknya dapat diarahkan untuk mengembangkan suatu kemampuan atau skil tertentu salah satunya kemampuan literasi kuantitatif.

Fakta menunjukkan bahwa dalam kegiatan praktikum biologi siswa jarang dihadapkan pada pengalaman kuantitatif dalam menghasilkan data pengamatan (Supriatno, 2018). Padahal kegiatan praktikum dalam biologi berpotensi untuk diarahkan pada kemampuan matematis atau literasi kuantitatif karena di dalamnya seringkali banyak melakukan percobaan yang menghasilkan data, merepresentasikan data dan menginterpretasikannya. Beberapa penelitian menunjukkan bahwa kegiatan praktikum biologi dapat dibuat menjadi lebih kuantitatif sehingga bisa menunjang literasi kuantitatif siswa (Ardiansyah et al., 2014; Meisadewi et al., 2017; Nuraeni, 2016; Riyaldi, 2019). Dengan demikian kegiatan praktikum biologi sangat memungkinkan untuk dapat memfasilitasi keterampilan literasi kuantitatif siswa.

Salah satu kegiatan praktikum biologi yang berpotensi untuk menunjang keterampilan literasi kuantitatif siswa adalah pada materi respirasi anaerob. Praktikum ini dapat diarahkan pada beberapa indikator keterampilan literasi kuantitatif. Beberapa kegiatan pengukuran yang mungkin dilakukan pada kegiatan tersebut adalah mengukur temperatur, mengukur volume gas hasil respirasi, dan menghitung laju respirasi. Sehingga kegiatan representasi data seperti menyajikan tabel dan grafik sangat memungkinkan untuk dilakukan. Seringkali praktikum biasa dan eksperimen saling dipertukarkan (Rustaman et al., 2016). Praktikum respirasi anaerob yang umum dilakukan di sekolah adalah kegiatan percobaan fermentasi oleh ragi untuk membuktikan proses respirasi anaerob dan zat-zat yang dihasilkan dimana kegiatan tersebut masih bersifat verifikasi konsep saja belum mengarah pada kegiatan yang sifatnya pengukuran dan eksperimen.

Berdasarkan uraian diatas, untuk menunjang kebutuhan tuntutan keterampilan literasi kuantitatif melalui kegiatan pembelajaran melalui kegiatan praktikum biologi khususnya materi respirasi anaerob, maka diperlukan sebuah desain kegiatan laboratorium untuk respirasi anaerob yang tidak hanya berupa kegiatan verifikasi saja melainkan kegiatan yang bersifat eksperimen serta mendukung pada kegiatan pengukuran dan kuantifikasi.

\section{METODE}

Metode penelitian ini adalah deskriptif, untuk memperoleh gambaran mengenai kualitas Desain Kegiatan Laboratorium (DKL) Respirasi Anaerob yang tersedia di lapangan serta mengembangkan DKL alternatif untuk memfasilitasi keterampilan literasi kuantitatif siswa. Penelitian ini menggunakan pendekatan ANBUCOR yang terdiri atas tahap analisis, buat, coba, 
dan rekonstruksi (Supriatno, 2013). Bagan alur penelitian ditampilkan pada Gambar 1. Tahap awal dari penelitian ini adalah kegiatan analisis terhadap DKL yang tersedia di lapangan. Analisis DKL ini meliputi aspek relevansi dengan kurikulum, kompetensi, praktikal, dan konstruksi pengetahuan. Tahapan berikutnya adalah pembuatan DKL alternatif meliputi perancangan dan pembuatan alat dan lembar kerja praktikum. Perancangan DKL alternatif juga disertai dengan proses validasi oleh ahli. Kemudian tahap uji coba dengan mengujicobakan DKL alternatif pada siswa. Tahap terakhir yaitu rekonstruksi DKL berdasarkan bahan perbaikan yang diperoleh pada tahap uji coba.

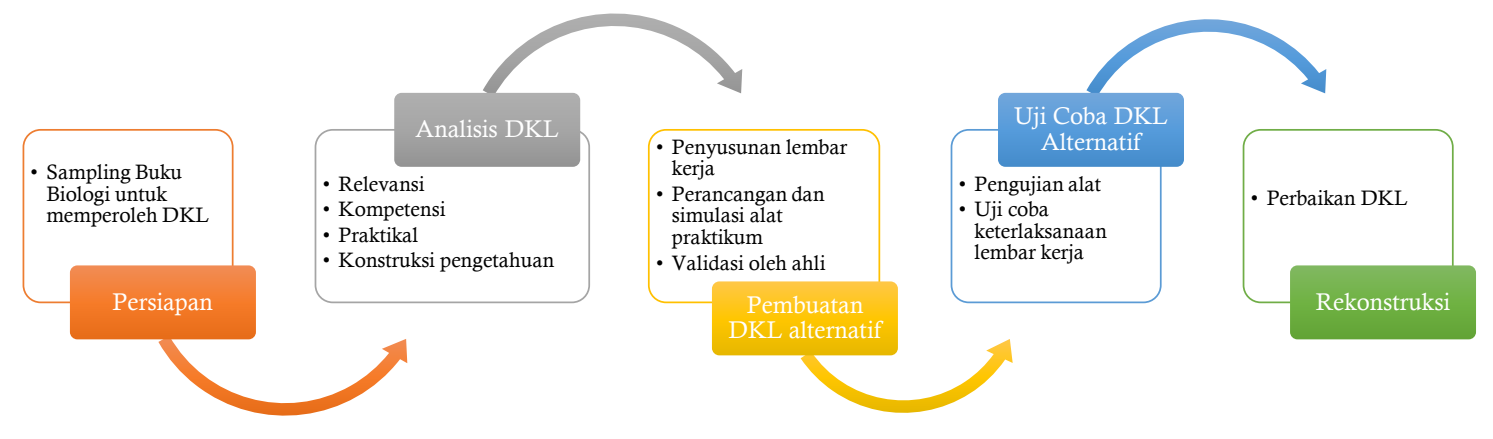

Gambar 1. Alur penelitian

Penelitian ini menggunakan 23 buku biologi kelas XII sebagai sampel yang ditentukan secara purposive. Sampel merupakan buku ajar yang memuat materi respirasi anaerob yang berlaku pada kurikulum KBK, KTSP, Kurikulum 2013, dan Kurikulum 2013 Revisi. Berdasarkan temuan di lapangan, tidak semua buku terdapat lembar kerja praktikum tentang percobaan respirasi anaerob. Kegiatan praktikum tentang respirasi anaerob hanya terdapat pada 5 buku yang berlaku pada kurikulum 2013 dan kurikulum 2013 Revisi (2016). Oleh karena itu DKL yang akan dianalisis hanya berjumlah 5. Penelitian ini juga melibatkan 3 orang siswa SMA kelas XII dan 2 orang ahli dalam praktikum biologi sebagai responden.

Instrumen yang digunakan dalam penelitian ini meliputi rubrik penilaian untuk tahap analisis (relevansi, kompetensi, praktikal, dan konstruksi pengetahuan) dan catatan lapangan. Kisi-kisi instrumen yang digunakan untuk analisis DKL disajikan pada Tabel 1. Rubrik analisis relevansi terdiri dari 2 indikator dengan skor minimal 1 dan skor maksimal 3. Adapun rubrik untuk analisis kompetensi terdiri atas 4 indikator dengan skor minimal 1 dan skor maksimal 4 . Rubrik analisis praktikal terdiri dari 3 indikator dengan skor minimal 1 dan skor maksimal 4. Rubrik analisis konstruksi pengetahuan terdiri atas 5 indikator yang diadaptasi dari (Novak \& Gowin, 1984). 
Tabel 1. Kisi-kisi rubrik analisis DKL

\begin{tabular}{ll}
\hline \multicolumn{1}{c}{ Analisis } & \multicolumn{1}{c}{ Indikator } \\
\hline Relevansi & 1. Relevansi kompetensi kegiatan dengan kompetensi dasar \\
& 2. Relevansi konten kegiatan dengan kompetensi dasar \\
\hline Kompetensi & 1. Kemampuan observasi melalui kegiatan \\
& 2. Kemampuan representasi data melalui kegiatan \\
& 3. Kemampuan interpretasi data melalui kegiatan \\
& 4. Level kemampuan berpikir melalui kegiatan \\
\hline Praktikal & 1. Kesesuaian alat praktikum dengan standar lab sekolah \\
& 2. Kesesuaian bahan praktikum dengan standar lab sekolah \\
& 3. Struktur langkah kerja \\
\hline Konstruksi Pengetahuan & 1. Judul/ Tujuan/ Pertanyaan fokus \\
(Novak \& Gowin, 1984) & 2. Objek/ Fenomena \\
& 3. Teori, prinsip, dan konsep \\
& 4. Perekaman dan transformasi data \\
& 5. Perolehan pengetahuan \\
\hline
\end{tabular}

Data penelitian dianalisis secara kuantitatif maupun kualitatif. Data hasil analisis disajikan dalam bentuk persentase. Digunakan interpretasi nilai persentase untuk memudahkan penafsiran terhadap nilai persentase yang diperoleh (Wasito, 1992). Nilai $0 \%$ berarti tidak satupun, $1-25 \%$ berarti sebagian kecil, 26 - 49\% berarti hampir sebagian, 50\% berarti sebagian, 51 - 75\% berarti sebagian besar, 76 - 99\% berarti hampir seluruhnya, dan untuk nilai 100\% berarti seluruhnya.

\section{HASIL DAN PEMBAHASAN}

\section{Analisis terhadap DKL Lapangan}

Analisis secara komprehensif dilakukan untuk menggambarkan kualitas dari desain kegiatan laboratoirum (DKL) yang tersedia di lapangan. DKL lapangan diperoleh dari buku-buku biologi kelas XII yang berlaku pada kurikulum 2013 dan kurikulum 2013 revisi. Hal tersebut telah sejalan dengan perkembangan kurikulum yang berlaku dimana pada kurikulum 2013 dinyatakan secara eksplisit mengenai tuntutan untuk melakukan kegiatan percobaan tentang respirasi anaerob. Kegiatan praktikum respirasi anaerob ini terkait dengan Kompetensi Dasar 3.2 yaitu menjelaskan proses metabolisme yang meliputi peran sebagai reaksi enzimatis dalam makhluk hidup, dan $\mathrm{KD} 4.2$ yaitu menyusun laporan hasil percobaan tentang mekanisme kerja enzim, fotosintesis dan respirasi anaerob.

Analisis DKL terbagi menjadi empat bagian yaitu analisis relevansi, analisis kompetensi, analisis praktikal, dan analisis konstruksi pengetahuan. Analisis relevansi menilai kesesuaian DKL sesuai dengan kurikulum. Kemudian analisis kompetensi dilakukan untuk mengetahui sejauh mana DKL melibatkan keterampilan-keterampilan khusus seperti observasi, representasi data, interpretasi data, dan kemampuan kognitif. Analisis praktikal menggambarkan ketersediaan alat dan bahan untuk melakukan kegiatan praktikum serta keterlaksanaan kegiatan melalui langkah kerja pada DKL. Sedangkan analisis konstruksi pengetahuan dilakukan untuk mengetahui 
bagaimana objek/ fenomena yang diobservasi dan dicatat pada kegiatan praktikum dapat digunakan untuk membangun pengetahuan siswa.

Analisis relevansi didasarkan pada komponen kegiatan praktikum meliputi isi kegiatan praktikum yang tergambar melalui kesesuaian antara judul/ tujuan, langkah kerja, proses pengamatan, dan hasil pengamatan. Analisis relevansi terdiri atas dua indikator yaitu relevansi kompetensi dalam kegiatan dengan tuntutan $K D$ dan relevansi konten dalam kegiatan dengan tuntutan $K D$. Indikator relevansi kompetensi dilihat berdasarkan perolehan dari kegiatan praktikum itu sendiri dan dilihat kesesuaiannya dengan tuntutan/ standar minimal pada kompetensi dasar. Sedangkan indikator relevansi konten ditentukan berdasarkan cakupan konsep esensial maupun konsep lain yang mendukung kegiatan praktikum. Indikator relevansi kompetensi memiliki skor maksimal apabila level pengetahuan pada kegiatan melebihi standar minimal dari kompetensi dasar (KD). Sedangkan pada indikator relevansi konten memiliki skor maksimal apabila cakupan konten pada kegiatan melebihi standar minimal dari kompetensi dasar (KD).

Berdasarkan temuan pada indikator relevansi kompetensi dapat diketahui bahwa sebanyak 80\% DKL yang tersedia di lapangan hanya memenuhi kriteria skor 2 (Gambar 2). Hal ini menunjukkan bahwa kompetensi pada hampir seluruh DKL hanya memenuhi standar minimal dari kompetensi dasar $(\mathrm{KD})$. Level pengetahuan minimal sesuai dengan tuntutan kurikulum untuk KD terkait materi ini adalah pada level memahami (C2). Penelitian lain menjelaskan bahwa level kognitif yang dituntut melalui kegiatan praktikum umumnya pada kemampuan mengingat, memahami, dan menerapkan saja (Wahidah et al., 2018).

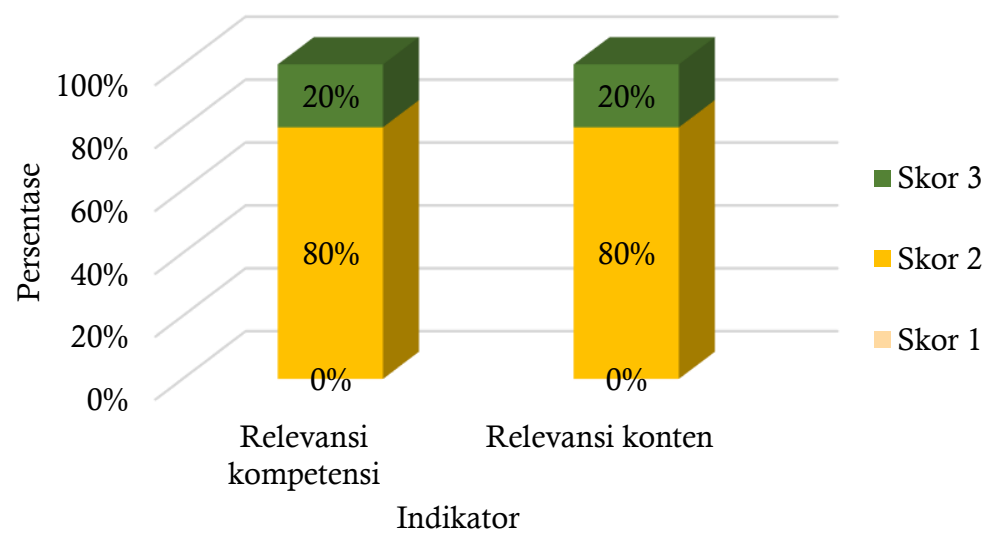

Gambar 2. Hasil analisis relevansi DKL dengan kurikulum

Hasil yang sama ditunjukkan pada indikator relevansi konten. Berdasarkan temuan diperoleh 80\% DKL lapangan hanya memenuhi kriteria skor 2 (Gambar 2). Hal ini berarti bahwa konten kegiatan praktikum pada hampir seluruh DKL hanya memenuhi standar minimal dari kompetensi dasar (KD). Cakupan materi pada DKL umumnya tentang proses dan hasil reaksi dari peristiwa 
respirasi anaerob. Hal ini sesuai dengan standar minimal $\mathrm{KD}$ yang hanya menjelaskan proses respirasi anaerob sebagai reaksi enzimatis saja. Konten pada praktikum biologi dikatakan sangat baik jika kegiatan dapat menggambarkan konsep utama dan melibatkan konsep lain baik tentang biologi maupun di luar biologi (Giriyanti, 2020).

Analisis kompetensi dilakukan untuk mengetahui sejauh mana kegiatan praktikum dapat mengembangkan kemampuan-kemampuan siswa seperti kemampuan berpikir, kemampuan observasi, keterampilan representasi data, dan keterampilan menginterpretasi data. Belajar melalui praktikum bukan sekedar belajar tentang konten melainkan juga memberi pengalaman belajar sehingga siswa dapat membangun keterampilan untuk memperoleh pengetahuan (Supriatno, 2018). Analisis ini didasarkan pada tuntutan kegiatan yaitu komponen langkah kerja, perekaman data, dan pertanyaan pengarah pada DKL. Hasil analisis kompetensi pada DKL disajikan pada Gambar 3 berikut.

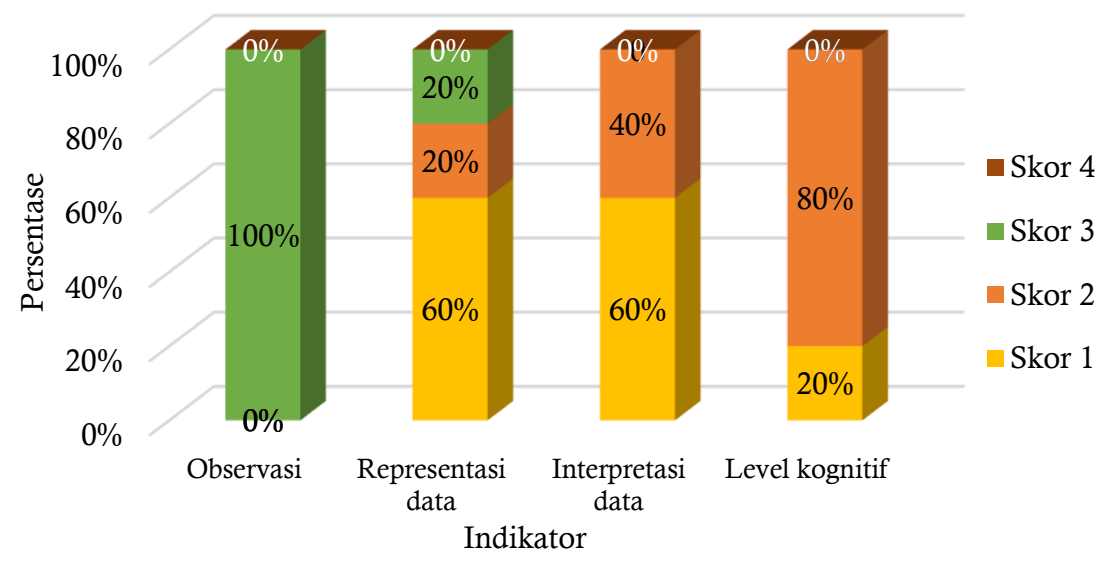

Gambar 3. Hasil analisis kompetensi pada DKL

Analisis kompetensi memuat empat indikator dengan skor minimal 1 dan skor maksimal 4. Indikator kemampuan observasi melalui kegiatan memiliki skor maksimal jika kegiatan observasi mampu mengarahkan pada karakter umum dan karakter spesifik dan mendukung perolehan pengetahuan. Indikator kemampuan representasi data melalui kegiatan memiliki skor maksimal jika data pengamatan disajikan kedalam bentuk tabel/ grafik secara tepat dan membantu proses interpretasi data. Sedangkan indikator kemampuan interpretasi data melalui kegiatan akan mencapai skor maksimal apabila seluruh komponen data pengamatan dapat diinterpretasi dan melibatkan pengetahuan lain yang mendukung interpretasinya. Indikator yang terakhir adalah level kemampuan kognitif. Capaian pada indikator ini ditentukan berdasarkan level kemampuan pada kegiatan. Skor maksimal diperoleh jika DKL mampu melibatkan kemampuan berpikir tingkat tinggi level mencipta (C6). 
Berdasarkan hasil temuan pada Gambar 3, diperoleh bahwa aspek kemampuan observasi memiliki capaian yang paling baik dari semua indikator lain. Temuan pada indikator observasi diperoleh bahwa 100\% DKL memenuhi kriteria skor 3. Hal ini berarti bahwa kegiatan pada seluruh DKL telah menuntut pada kemampuan mengobservasi karakter umum dan karakter spesifik dari objek atau peristiwa. Data pengamatan pada DKL umumnya masih berupa data kualitatif (deskriptif). Sedangkan kegiatan observasi berupa pengukuran yang teridentifikasi pada DKL diantaranya adalah mengukur temperatur saja. Kemampuan observasi ini sangat penting dalam kegiatan praktikum. Ketepatan observasi dalam praktikum sangat menentukan konstruksi pengetahuan pada siswa (Supriatno, 2018).

Di sisi lain terdapat aspek kompetensi yang masih lemah diantaranya pada indikator kemampuan interpretasi data dan kemampuan representasi data. Capaian didominasi oleh skor rendah. Hasil temuan menunjukkan bahwa 60 \% DKL memiliki skor 1 dan 40\% lainnya memenuhi kriteria skor 2 (Gambar 3). Ini berarti bahwa pada sebagian besar DKL data pengamatan yang diperoleh tidak diinterpretasi dengan baik. Beberapa DKL sama sekali tidak memberikan petunjuk atau pertanyaan pengarah untuk memaknai data hasil pengamatan. Padahal interpretasi data sangat penting untuk mendukung perolehan pengetahuan melalui kegiatan praktikum. Salah satu keterampilan yang perlu dikuasai oleh siswa yang belajar sains adalah keterampilan interpretasi data, karena interpretasi data berkaitan dengan pemahaman dan pemberian makna terhadap data atau informasi (Latifah et al., 2017).

Masih lemahnya capaian aspek interpretasi data terkait dengan bentuk penyajian data (representasi data) yang juga masih kurang. Sama halnya dengan capaian pada aspek interpretasi, aspek representasi data juga masih didominasi oleh skor $1(60 \%)$. Hal ini berarti bahwa pada sebagian DKL kegiatan tidak ditemukan kegiatan pengubahan bentuk data, bahkan terdapat DKL yang tidak menuntut kegiatan penyajian data. Padahal dengan dapat diperolehnya data kuantitatif kemudian data ditransformasikan menjadi grafik dapat mengembangkan berbagai keterampilan proses berfikir dan kompetensi (Supriatno, 2018).

Analisis praktikal dilakukan untuk menguji keterlaksanaan DKL lapangan melalui kegiatan uji coba. Analisis praktikal dinilai berdasarkan tujuh indikator Adapun parameter yang dianalisis meliputi sistematika/ urutan langkah kerja dan keterlaksanaannya, serta ketersediaan alat dan bahan yang digunakan untuk praktikum. Suatu produk dinilai praktis apabila produk tersebut realistis dan dapat digunakan (Akker et al., 2010). Hasil analisis praktikal disajikan pada Gambar 4 berikut. 


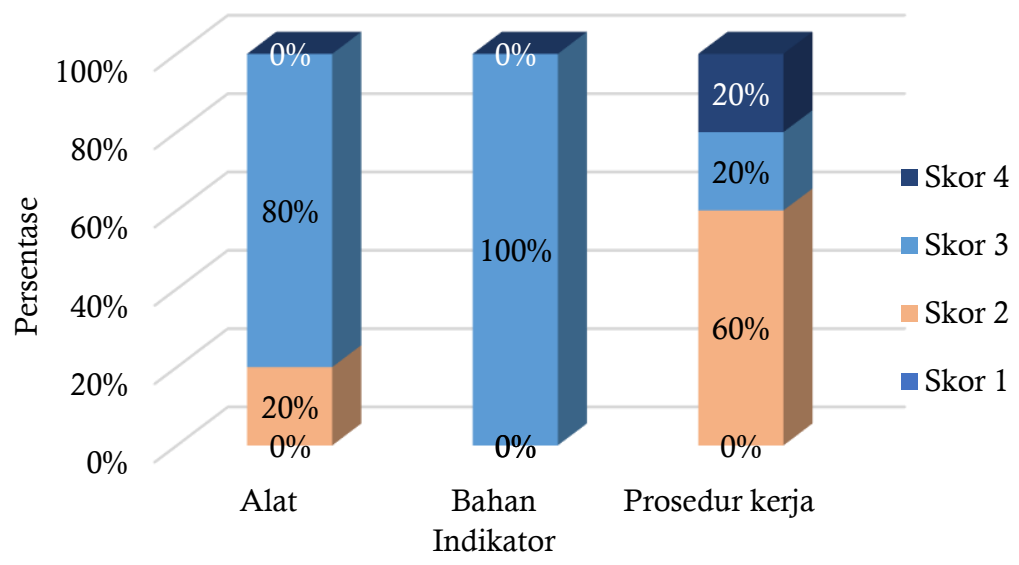

Gambar 4. Hasil analisis praktikal

Berdasarkan hasil temuan pada Gambar 4, permasalahan ditemukan pada indikator struktur langkah kerja dimana 60\% DKL yang dianalisis hanya mencapai skor 2. Capaian ini menunjukkan bahwa sebagian besar DKL memiliki langkah kerja yang kurang terstruktur, namun terdapat beberapa urutan kerja yang sesuai untuk mendapatkan hasil pengamatan. Prosedur praktikum meskipun rinci, beberapa di antaranya tidak terstruktur dan perintahnya membingungkan sehingga menimbulkan penafsiran ganda (Supriatno, 2013).

Pada aspek ketersediaan alat praktikum diperoleh bahwa tidak semua alat yang digunakan pada sebagian besar DKL dapat ditemukan pada skala laboratorium sekolah namun beberapa diantaranya dapat diganti dengan alat alternatif. Temuan pada aspek ketersediaan bahan praktikum diperoleh bahwa seluruh DKL hanya memenuhi kriteria skor 2. Hal ini berarti bahwa tidak semua bahan yang digunakan pada kegiatan dapat diperoleh pada skala laboratorium sekolah. Namun beberapa bahan diantaranya dapat diganti dengan bahan alternatif. Misalnya bahan Kalsium Hidroksida dapat diganti dengan bahan alternatif seperti kapur sirih bisa digunakan.

Kualitas suatu DKL dapat ditentukan berdasarkan karakteristik konstruksi pengetahuan. Analisis ini didasarkan pada kemunculan komponen Diagram Vee (Novak \& Gowin, 1984). Konstruksi pengetahuan melibatkan proses membangun pemahaman konsep berdasarkan proses mengobservasi objek/ fenomena, mencatat dan mentransformasi data, serta menghubungkan teori dengan hasil pengamatan. Komponen Diagram vee meliputi: 1) Judul/ tujuan/ pertanyaan fokus, 2) Objek/ peristiwa 3) Teori, prinsip, dan konsep, 4) Perekaman dan transformasi data, dan 5) Perolehan pengetahuan. Indikator 1 dan 2 memiliki skor maksimal 3 sedangkan indikator 3,4, dan 5 memiliki skor maksimal 4. Hasil analisis aspek konstruksi pengetahuan pada DKL lapangan dapat dilihat pada Gambar 5. 


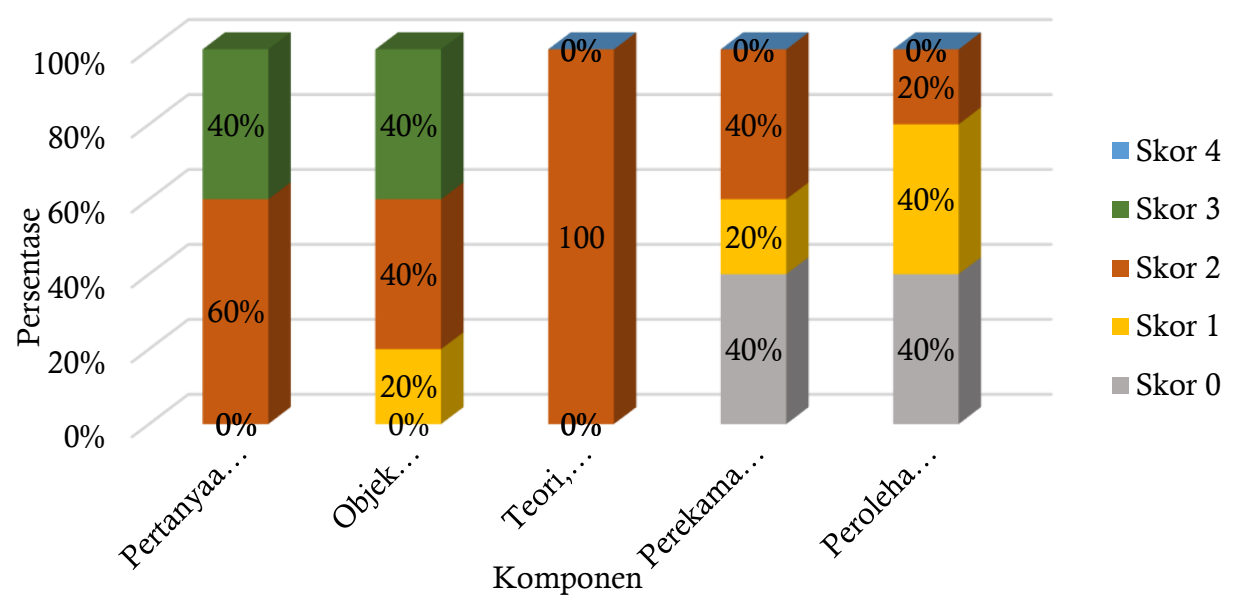

Gambar 5. Hasil analisis konstruksi pengetahuan berdasarkan kemunculan komponen Diagram Vee

Berdasarkan temuan pada Gambar 5, dapat dilihat bahwa semua komponen Diagram Vee dapat ditemukan pada keseluruhan DKL yang dianalisis. Capaian paling baik terdapat pada indikator pertanyaan fokus dimana 60\% DKL memperoleh skor 2 dan 40\% lainnya memperoleh skor 3. Hal ini menunjukkan bahwa pertanyaan fokus teridentifikasi pada DKL melalui judul/ tujuan dan mengandung bagian konseptual. Pertanyaan fokus dalam DKL harus mengarahkan pada objek/fenomena yang harus diobservasi (Novak \& Gowin, 1984). Pertanyaan fokus pada DKL dapat mengarahkan siswa untuk memperoleh apa yang seharusnya mereka peroleh/ temukan melalui kegiatan laboratorium (Abrahams \& Millar, 2008).

Meskipun semua komponen Diagram Vee dapat teridentifikasi pada setiap DKL, namun masih terdapat beberapa komponen yang belum menunjukkan hasil optimal. Pada Gambar 5 terlihat bahwa komponen teori, prinsip, dan konsep belum menunjukkan capaian yang baik dimana semua (100\%) DKL hanya memperoleh skor 2 . Hal ini menunjukkan bahwa hanya sedikit konsep yang bisa diidentifikasi pada DKL. Kegiatan pada DKL yang tersedia di lapangan hanya menuntun siswa untuk melakukan kegiatan verifikasi atau konfirmasi terkait proses dan hasil dari reaksi respirasi anaerob. Kegiatan laboratorium yang dilakukan oleh siswa menjadi tidak bermakna apabila kegiatan yang ada hanya bersifat verifikasi atau konfirmasi saja (Hindriana, 2020).

Hal yang sama terjadi pada komponen perekaman dan transformasi dimana skor rendah masih cukup banyak ditemukan. Berdasarkan data temuan pada Gambar 5, skor 0 pada komponen ini diperoleh sebanyak 40\%. Hal ini menunjukkan bahwa hampir sebagian DKL yang tersedia di lapangan tidak terdapat kegiatan pencatatan atau transformasi data. Jika komponen perekaman dan transformasi data tidak terdapat pada DKL, maka kegiatan tersebut kurang memfasilitasi proses metakognitif siswa dalam memahami dan memaknai hasil observasi (Supriatno, 2013). 
Kegiatan perekaman dan transformasi data yang masih lemah akan berdampak pula pada perolehan pengetahuan. Temuan juga menjelaskan bahwa keberadaan komponen perolehan pengetahuan pada masing-masing skor 0 dan 1 diperoleh sebanyak 40\% (Gambar 5). Hal ini menunjukkan bahwa hampir sebagian dari DKL yang dianalisis belum mengarah pada perolehan pengetahuan. Hal ini dikarenakan proses penarikan kesimpulan sampai dengan memperoleh perolehan pengetahuan masih lemah karena pertanyaan yang belum terstruktur (Ekselsa et al., 2020).

\section{Pembuatan DKL alternatif}

Hasil temuan analisis terhadap DKL yang tersedia di lapangan dijadikan dasar peneliti untuk membuat sebuah DKL sebagai alternatif. Tahap pembuatan DKL alternatif ini meliputi perancangan alat praktikum dan lembar kerja praktikum. Tahap ini dilakukan dengan tujuan agar diperoleh suatu DKL materi respirasi anaerob yang dapat memfasilitasi keterampilan literasi kuantitatif siswa. Dimana masyarakat modern saat ini dituntut untuk meningkatkan penggunaan berpikir kuantitatif di dalam pendidikan maupun pekerjaan sehari-hari (Steen et al., 2001).

Beberapa hal yang menjadi bahan untuk pengembangan kegiatan pada DKL alternatif diantaranya adalah pada cakupan konten dimana penekanan materinya pada reaksi enzimatis dari peristiwa reaksi anaerob berikut faktor-faktor yang mempengaruhinya. Selain itu, konsep kegiatan pada DKL alternatif ini berupa kegiatan yang bersifat eksperimen dari sebelumnya yang hanya berupa kegiatan verifikasi saja atau bersifat non eksperimen. Kegiatan eksperimen yang dibuat berupa menemukan pengaruh temperatur terhadap laju respirasi anaerob.

Perancangan alat praktikum menjadi bagian penting dari tahap pembuatan DKL alternatif. Bahan utama alat ini menggunakan labu erlenmeyer dengan pipa samping sebagai tempat berlangsungnya reaksi, tabung ukur sebagai pengukur volume gas, dan pipa plastik untuk menghubungkan labu dengan tabung ukur. Alat tambahan lain meliputi termometer, three way stopcock, dan spuit. Gambar alat praktikum serta spesifikasinya dapat dilihat pada Gambar 6. Labu erlenmeyer digunakan agar perangkat mudah diletakan. Alat ini dapat diletakan pada penangas sehingga percobaan bisa dilakukan pada perlakuan temperatur lingkungan yang berbeda. Dengan begitu data laju respirasi dapat diperoleh dari berbagai faktor temperatur yang dimanipulasi.

Alat praktikum pada DKL alternatif dirancang untuk mendukung kegiatan eksperimen yang akan dilakukan oleh siswa. Alat praktikum akan mendukung kegiatan pengukuran diantaranya untuk mengukur temperatur reaksi dan mengukur volume gas yang dihasilkan selama proses respirasi anaerob berlangsung. Dengan demikian pada DKL alternatif ini akan diperoleh sejumlah data kuantitatif berupa temperatur dan laju respirasi anaerob sehingga dapat menunjang kompetensi siswa berkaitan dengan keterampilan literasi kuantitatif. 


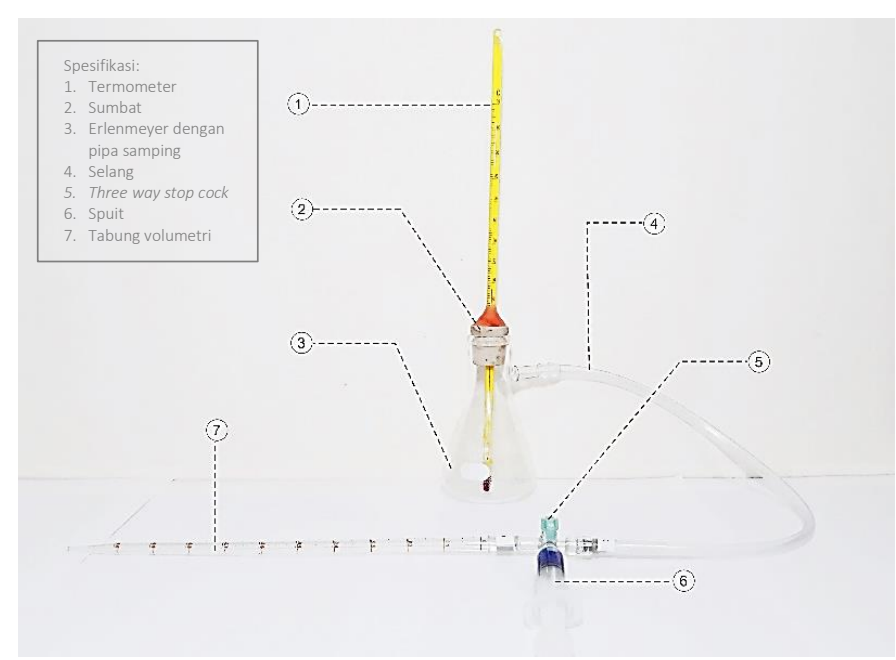

Gambar 6. Alat praktikum untuk DKL alternatif

Terkait dengan pemaparan analisis kompetensi dimana aspek representasi dan interpretasi data yang masih lemah, pada DKL alternatif ini akan dioptimalkan melalui pelibatan komponen keterampilan literasi kuantitatif pada lembar kerja praktikum. Keterampilan literasi kuantitatif mencakup komponen interpretasi, representasi, kalkulasi, analisis, asumsi dan komunikasi (Association of American Colleges and Universities (AAC\&U), 2009). Keberadaan komponen literasi kuantitatif pada DKL alternatif disajikan pada Tabel 2. Komponen literasi kuantitatif yang terdapat pada DKL alternatif adalah aspek kalkulasi, representasi, interpretasi, dan Analisis/ Aplikasi.

Tabel 2. Keberadaan komponen literasi kuantitatif pada DKL alternatif

\begin{tabular}{cl}
\hline $\begin{array}{c}\text { Komponen Literasi } \\
\text { Kuantitatif }\end{array}$ & \multicolumn{1}{c}{ Uraian } \\
\hline Kalkulasi & $\begin{array}{l}\text { Kegiatan menghitung laju respirasi anaerob. Aspek ini terdapat pada bagian } \\
\text { perekaman data hasil pengamatan. } \\
\text { Kegiatan mengubah bentuk data data pengamatan dari tabel ke dalam bentuk } \\
\text { grafik. Komponen ini terdapat pada bagian perekaman dan transformasi data } \\
\text { (Hasil pengamatan). }\end{array}$ \\
Interpretasi & $\begin{array}{l}\text { Kegiatan menginterpretasi data pengamatan berupa grafik. Terdapat pada } \\
\text { bagian pertanyaan pengarah. }\end{array}$ \\
Analisis/ Aplikasi & $\begin{array}{l}\text { Kegiatan untuk menganalisis pengaruh temperatur terhadap laju respirasi } \\
\text { berdasarkan data yang disajikan pada grafik. Terdapat pada bagian pertanyaan } \\
\text { pengarah. }\end{array}$ \\
\hline
\end{tabular}

Aspek kalkulasi pada literasi kuantitatif meliputi kemampuan untuk melakukan perhitungan (Association of American Colleges and Universities (AAC\&U), 2009). Aspek kalkulasi ini terdapat pada bagian perekaman data hasil pengamatan. Pada bagian tersebut siswa akan diminta untuk 
melakukan penghitungan laju respirasi anaerob rata-rata pada setiap kondisi temperatur yang berbeda dari data berupa jumlah volume gas dan waktu yang mereka ukur.

Komponen literasi kuantitatif lain yang terdapat pada DKL alternatif ini adalah representasi. Aspek ini terdapat pada bagian transformasi data. Data pengamatan dalam bentuk tabel yang diperoleh akan diubah kedalam bentuk grafik oleh siswa. Aspek representasi meliputi kemampuan untuk mengubah informasi yang sesuai kedalam berbagai bentuk matematis misalnya persamaan, grafik, diagram, tabel atau kata - kata (Nuraeni et al., 2014).

Interpretasi dalam literasi kuantitatif merupakan suatu kegiatan bernalar dengan data, membaca grafik, menggambarkan kesimpulan, dan mengenali sumber-sumber kesalahan (Nuraeni et al., 2014). Pada DKL alternatif kegiatan berkaitan dengan proses interpretasi data kuantitatif terdapat pada bagian pertanyaan pengarah. Pada bagian tersebut siswa diminta untuk membaca grafik dari data hasil pengamatan. Kegiatan interpretasi meliputi membandingkan data laju respirasi pada berbagai perlakuan temperatur, kemudian menggambarkan hubungan yang diperlihatkan oleh grafik hasil pengamatan.

Komponen lain dari literasi kuantitatif yang dilibatkan ada DKL alternatif adalah analisis/ aplikasi. Aspek ini meliputi kemampuan membuat keputusan dan membuat kesimpulan yang tepat berdasarkan analisis data kuantitatif (Association of American Colleges and Universities (AAC\&U), 2009). Pada DKL alternatif, aspek ini berada pada bagian pertanyaan pengarah untuk membentuk pengetahuan. Pada bagian ini siswa diminta untuk membuat kesimpulan didasarkan pada data - data pengamatan yang mereka peroleh.

\section{Uji coba DKL alternatif}

Tahap ini bersifat uji coba terbatas. Alat praktikum yang telah dirancang kemudian diujicobakan untuk menguji keterpakaian mengetahui masalah yang mungkin timbul saat digunakan. Pengujian ini dilakukan untuk memastikan bahwa alat berfungsi sesuai yang diharapkan sehingga dapat memperoleh hasil pengamatan yang tepat. Selain itu juga dilakukan penentuan takaran ragi dan glukosa yang tepat disesuaikan dengan kemampuan alat dalam mengukur volume gas. Hasil pengujian takaran ragi dan glukosa diperoleh bahwa alat praktikum efektif untuk mengukur pada takaran ragi pada kisaran 0,1 - 2 gr.

Uji coba juga dilakukan terhadap lembar kerja praktikum yang telah dirancang. Kegiatan uji coba ini dilakukan oleh siswa sesuai jenjang terkait untuk mengetahui keterlaksanaan urutan langkah kerja serta untuk menggali informasi mengenai masalah-masalah yang dihadapi siswa saat melakukan praktikum. Hasil pada uji coba diperoleh bahwa terdapat urutan langkah kerja yang membingungkan. Urutan langkah kerja yang bermasalah terdapat pada poin 4 dan 5 (Gambar 7). 
4. Setelah suhu tercapai, atur keran triway stopcock sejajar titik A, kemudian masukan
sedikit zat pewarna melalui titik $\mathrm{C}$ menggunakan spuit $5 \mathrm{~mL}$ berisi zat pewarna.
5. Atur keran triway stopcock sejajar titik $\mathrm{B}$, gunakan stopwatch untuk mencatat waktu
kemudian amati pergerakan zar pewarna catat jumlah gas yang dihasilkan dan waktu
yang dibutuhkan.

Gambar 7. Permasalahan pada langkah kerja poin 4 dan 5

Kemudian dari aspek ketersediaan alat bahan, masalah yang ditemukan pada tahap uji coba diantaranya tidak tersedianya bahan berupa glukosa pada laboratorium sekolah. Ketiadaan bahan ini terjadi dimungkinkan karena masih belum optimalnya pengelolaan lab biologi di sekolah tersebut. Hal ini sesuai dengan temuan penelitian yang menyatakan bahwa pengetahuan dan pemahaman guru biologi SMA dalam merancang dan mengelola Laboratorium biologi masih kurang (Susilo \& Amirullah, 2018).

Hal lain yang ditemukan saat uji coba diperoleh bahwa siswa kurang bisa menggambarkan skala yang benar saat menggambarkan grafik. Padahal dengan menyediakan grafik, tabel, persamaan, atau gambar yang berkaitan dengan fenomena biologi, informasi yang akan disajikan dapat disesuaikan dengan kebutuhan siswa agar lebih mudah (Tsui \& Treagust, 2013). Oleh karena itu sebagai bahan perbaikan, DKL alternatif memerlukan garis bantu pada kolom untuk membuat grafik pada lembar kerja praktikum.

\section{Rekonstruksi DKL alternatif}

Tahap terakhir dari rangkaian pengembangan DKL ini adalah tahap rekonstruksi. Hal-hal yang menjadi catatan selama kegiatan uji coba menjadi bahan perbaikan pada DKL alternatif sehingga kegiatan pada DKL alternatif ini bisa dilaksanakan seoptimal mungkin. Perbaikan fokus pada aspek praktikal dan keterlaksanaan kegiatan. Beberapa hal yang diperbaiki pada DKL alternatif diantaranya perbaikan struktur kalimat pada beberapa urutan langkah kerja dan penambahan gambar (Gambar 8).

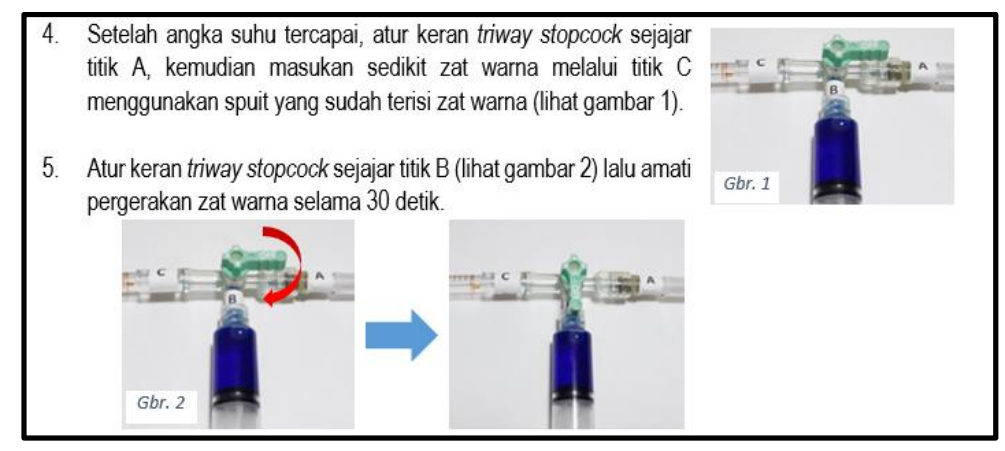

Gambar 8. Perbaikan pada bagian langkah kerja 
Pada bagian perekaman dan transformasi data DKL alternatif menyediakan grid/ blok pada bagian penyajian data pengamatan untuk membantu siswa ketika menggambarkan skala grafik. Bagian paling menantang pada saat siswa mengonstruksi sebuah grafik adalah ketika mengatur skala (Nixon et al., 2016). Oleh karena itu blok atau grid (gridlines) sangat membantu untuk memperkirakan nilai yang akan mewakili poin yang terplot pada grafik (Setyowati, 2019).

\section{SIMPULAN}

Hasil analisis terhadap DKL yang terdapat di lapangan menunjukkan bahwa pada umumnya DKL telah relevan dengan tuntutan kurikulum. Akan tetapi masih terdapat kelemahan pada aspek kompetensi terutama pada indikator interpretasi dan representasi data. Temuan di lapangan menjadi bahan masukan bagi pengembangan DKL alternatif. Hasil dari pengembangan diperoleh DKL alternatif bersifat eksperimen. DKL hasil pengembangan mencakup lembar kerja dan alat praktikum yang mendukung kegiatan kuantifikasi. Lembar kembar kerja pada DKL alternatif juga didukung oleh keberadaan beberapa komponen literasi kuantitatif diantaranya kalkulasi, interpretasi, representasi, dan analisis/ aplikasi. Dengan demikian DKL alternatif untuk materi respirasi anaerob yang dikembangkan tersebut dapat memfasilitasi keterampilan literasi kuantitatif siswa.

\section{REFERENSI}

Abrahams, I., \& Millar, R. (2008). Does practical work really work? A study of the effectiveness of practical work as a teaching and learning method in school science. International Journal of Science Education, 30(14), 1945-1969. https://doi.org/10.1080/09500690701749305.

Akker, J. van den, Bannan, B., Kelly, A. E., Nieveen, N., \& Plomp, T. (2010). An Introduction to Educational Design Research (T. Plomp \& N. Nieveen (eds.)). Netherlands institute for curriculum development. www.slo.nl

Ardiansyah, R., Survani, R., Nuraeni, E., Supriatno, B., \& Rahmat, A. (2014). Bahan Ajar Anatomi Tumbuhan untuk Menunjang Literasi Kuantitatif Mahasiswa Biologi. Prosiding Mathematics and Sciences Forum 2014, 411-416. http://prosiding.upgrismg.ac.id

Association of American Colleges and Universities (AAC\&U). (2009). Quantitative Literacy VALUE Rubric. https://www.aacu.org/value/rubrics/quantitative-literacy

Ekselsa, R. A., Supriatno, B., \& Anggraeni, S. (2020). Rekonstruksi dan Pengembangan Lembar Kerja Siswa pada Materi Plantae Submateri Spermatophyta dengan Pendekatan Keterampilan Proses. $\quad$ BIODIK, 6(4), 507-518. https://doi.org/https://doi.org/10.22437/bio.v6i4.9505

Gibson, J. P., \& Mourad, T. (2018). The growing importance of data literacy in life science 
education. In American Journal of Botany (Vol. 105, Issue 12, pp. 1953-1956). WileyBlackwell. https://doi.org/10.1002/ajb2.1195

Giriyanti, P. (2020). Analisis Perubahan Praktikum Difusi dan Osmosis [Universitas Pendidikan Indonesia]. http:repository.upi.edu

Hindriana, A. F. (2020). Pengembangan Lembar Kerja Praktikum Berbasis Diagram Vee Guna Memfasilitasi Kegiatan Laboratorium Secara Bermakna. Quagga: Jurnal Pendidikan Dan Biologi, 12(1), 62. https://doi.org/10.25134/quagga.v12i1.2331

Permendikbud No 24 Tahun 2016.

Kemp, M. (2003). Critical numeracy: helping people to decide. The Mathematic Education into 21st Century Project, $144-148$. http://dipmat.math.unipa.it/ grim/21_project/21_brno03_kemp.pdf

Latifah, R., Murni, F., \& Widoretno, S. (2017). Penerapan Guided Inquiry Learning untuk Meningkatkan Keterampilan Interpretasi Data Siswa Kelas XI IPA 4 Tahun Pelajaran 2016 / 2017 pada Materi Sistem Ekskresi Manusia The Implementation of Guided Inquiry Learning to Improve Students ' Interpretation Dat. Proceeding Biology Education Conference, 14, $355-360$.

Meisadewi, N., Anggraeni, S., \& Supriatno, B. (2017). Improving Students' Graphing Skills through Quantitative-Based Lab Activities. IOP Conference Series: Materials Science and Engineering, 180(1), 012245. https://doi.org/10.1088/1757-899X/180/1/012245

Nixon, R. S., Godfrey, T. J., Mayhew, N. T., \& Wiegert, C. C. (2016). Undergraduate student construction and interpretation of graphs in physics lab activities. Phys. Rev. Phys. Educ. Res., 12(1). https://doi.org/10.1103/PhysRevPhysEducRes.12.010104

Novak, J. D., \& Gowin, D. B. (1984). Learning How to Learn. Cambridge University Press. https://doi.org/10.1017/CBO9781139173469

Nuraeni, E. (2016). Program Perkuliahan Anatomi Tumbuhan Berbasis Kerangka Instuksional Dimensi Belajar Marazno untuk Mengembangkan Literasi Kuantitatif Mahasiswa [Universitas Pendidikan Indonesia]. http://repository.upi.edu

Nuraeni, E., Rahmat, A., Redjeki, S., \& Riandi. (2014). Profil Literasi Kuantitatif Mahasiswa Calon Guru Biologi. Prosiding Mathematics and Sciences Forum 2014, December 2019, 375-280.

Riyaldi, A. S. (2019). Peran Pembelajaran Sistem Pernapasan Menggunakan LKPD Berbasis Grafik dalam Meningkatkan Graphing Skills Siswa SMA [Universitas Pendidikan Indonesia]. http://repository.upi.edu

Rustaman, N., Dirdjosoemarto, S., Yudianto, S. A., Kusumastuti, M. N., Rochintaniawati, D., \& Achmad, Y. (2005). Strategi Belajar Mengajar. UM Press.

Rustaman, N., W, S. A., Widodo, A., Wulan, A. R., Rustaman, A., Sirdjosoemarto, S., Riandi, 
R., \& Kusumastuti, M. (2016). Strategi Pembelajaran Biologi. Universitas Terbuka. https://www.pustaka.ut.ac.id/lib/pebi4301-strategi-pembelajaran-biologi/

Setyowati, D. (2019). Pelatihan Membuat Grafik Dalam Microsoft Excel. Untuk Pengolahan Dan Penyajian Data. Jurnal Dharma Bakti-LPPM IST AKPRIND Yogyakarta, 2(2), 101-112.

Sevgi, L. (2006). Speaking with Numbers: Scientific Literacy and Public Understanding of Science. Turk J Elec Engin, 14(1), 33-40.

Skalicky, J. (2004). Quantitative Literacy in a Reform-based Curriculum and Implications for Assessment. AARE Annual Conference, 1-15.

Speth, E. B., Momsen, J. L., Moyerbrailean, G. A., Ebert-May, D., Long, T. M., Wyse, S., \& Linton, D. (2010). 1, 2, 3, 4: Infusing quantitative literacy into introductory biology. CBE Life Sciences Education, 9(3), 323-332. https://doi.org/10.1187/cbe.10-03-0033

Steen, L. A., Orril, R., \& Cohen, P. C. (2001). Mathematics And Democrarcy: The Case For Quantitative Literacy. National Council on Education and The Disciplines.

Supriatno, B. (2013). Pengembangan Program Perkuliahan Pengembangan Praktikum Biologi Sekolah Berbasis Ancorb untuk Mengembangkan Kemampuan Merancang Dan Mengembangkan Desain Kegiatan Laboratorium. Universitas Pendidikan Indonesia.

Supriatno, B. (2018). Praktikum untuk Membangun Kompetensi. Proceeding Biology Education Conference, 15, 18. https://jurnal.uns.ac.id/prosbi/article/viewFile/27558/19050

Susilo, S., \& Amirullah, G. (2018). Pengelolaan dan Pemanfaatan Laboratorium Sekolah bagi Guru Muhammadiyah di Jakarta Timur. Jurnal SOLMA, 7(1), 127. https://doi.org/10.29405/solma.v7i1.2380

Tsui CY., Treagust D.F. (2013) Introduction to Multiple Representations: Their Importance in Biology and Biological Education. In: Treagust D., Tsui CY. (eds) Multiple Representations in Biological Education. Models and Modeling in Science Education, vol 7. Springer, Dordrecht. https://doi.org/10.1007/978-94-007-4192-8_1

Wahidah, N. S., Supriatno, B., \& Kusumastuti, M. N. (2018). Analisis Struktur dan Kemunculan Tingkat Kognitif pada Desain Kegiatan Laboratorium Materi Fotosintesis. Assimilation: Indonesian Journal of Biology Education, 1(2), 70-76. https://doi.org/10.17509/aijbe.v1i2.13050

Wasito, H. (1992). Pengantar Metodologi Penelitian: buku panduan mahasiswa. Gramedia Pustaka Utama. 